\title{
Construct Validity and Reliability of Indonesian Version of RAND SF-36 Quality of Life Questionnaire in Breast Cancer Patients
}

\author{
Zhafirah Ramadhanty $^{1}$, Kristanto Yuli Yarsa ${ }^{2}$, Ari Probandari ${ }^{3}$ \\ ${ }^{1}$ Faculty of Medicine, Universitas Sebelas Maret, Surakarta, Indonesia \\ ${ }^{2}$ Department of Surgery, Oncology Division, Faculty of Medicine, Universitas Sebelas Maret, Surakarta, Indonesia \\ ${ }^{3}$ Department of Public Health, Faculty of Medicine, Universitas Sebelas Maret, Surakarta, Indonesia
}

\section{ARTICLE INFO}

Received : 18 January 2019

Reviewed: 23 January 2019

Accepted : 21 May 2019

\section{Keywords:}

breast cancer, RAND SF-36, reliability, validity

\author{
*Corresponding author: \\ Zhafirah Ramadhanty \\ Faculty of Medicine, Universitas \\ Sebelas Maret, Surakarta, Indonesia \\ Email: zhafirah@live.com
}

\begin{abstract}
Background: The number of breast cancer patients in Indonesia is increasing but there are still only a few researches that assess their quality of life. RAND SF-36 is a quality of life instrument that is widely used. In Indonesia, the validity and reliability of the instrument is still under development, especially in breast cancer patients. Various health status questionnaires have been used in physical rehabilitation studies involving patient with pacemaker, but for women with breast cancer, the usefulness of these questionnaires as measures of physical, mental, and social well-being has not been firmly established.
\end{abstract}

Methods: A previously validated RAND SF-36 questionnaire in patients with pacemaker was given to 252 breast cancer survivor community members. We assessed the construct validity and the reliability by referring to its Pearson's $r$ table value and Cronbach's $\alpha$ coefficient.

Results: One hundred and fourteen breast cancer survivor community members participated and completed all 36 questions of the instrument between SeptemberNovember 2018. Questions number 2, 28, and 35 showed lower Pearson's $r$ value $(r<0,300)$ than other questions but still showed $r$ value of $>0.1548$ indicating that these questions were valid. Cronbach's a coefficient $>0.90$ indicated good internal consistency.

Conclusions: The Indonesian version of the SF-36 quality of life questionnaire is a suitable instrument and can be used for research in Indonesian breast cancer patients.

\section{INTRODUCTION}

The number of breast cancer patients in Indonesia is increasing and the prevalence of the case is one of the highest among all type of cancers but there are still only a few researches regarding their quality of life in Indonesia [1-3]. Quality of life measurement should reflect the domains including the physical, social, and cultural environments, and it is common but also able to show the uniqueness of all subjects [4]. There are types of health-related quality of life measurements, such as general health profile, preference-based generic measures, and specific disease measures. RAND SF-36 is a health-related quality of life instrument that is widely used. The questionnaire is a generic measure that could be applied in any adult population. A good questionnaire is ideally valid and reliable, which means that the measurement reflects the concept and is consistent [5].

In Indonesia, the validity and reliability of the instrument is still on development, especially in breast cancer patients. A few validity and reliability test of the Indonesian version of the RAND SF-36 questionnaire has been done in a few groups of cancer patients, patients with permanent pacemaker, and rheumatoid arthritis patients [6-8]. Yet, none of the research has been done specifically in breast cancer patients. Perwitasari [8] validated the questionnaire in patients with cancer but the development of the questionnaire is still unsatisfying so that a future study with new construction of questions is needed to validate the Indonesian version of RAND SF-36 quality of life questionnaire. 


\section{METHODS}

\section{Patients}

The research was performed in breast cancer survivor community Lovely Pink Solo by filling an online form or interview by phone, chat, or meeting. A total of 252 community members were contacted between September to November 2018 and selected by the following inclusion criteria: (1) be at least 20 years of age, (2) able to complete the questionnaire by their own self, and (3) had no communication problem. The exclusion criteria are having a degenerative disease and/or mental illness so that it could affect the results of this research. Among 252 community members, only 114 agreed to participate in this study and completed the questionnaire.

\section{Instruments}

The RAND SF-36 measures physical and mental health which is divided into eight scales. Physical health aggregates from physical functioning (PF), role limitations due to physical problems (RP), bodily pain $(\mathrm{BP})$, and general health perception (GH). Mental health aggregates from role limitations due to role emotional (RE), vitality (VT), mental health $(\mathrm{MH})$, and social functioning (SF). The questionnaire also includes one question about health changes [9]. We used a previously translated SF-36 questionnaire by Salim [7]. His study translated the original version into the Indonesian language with forward-backward translation and also did some changes due to cultural adaptation. The changes included adding an explanation for the word "blocks" and "mile" in question number 9 and 10 because Indonesians are more familiar with the metric scale. Another adaptation was also made to make the questions more familiar to Indonesian breast cancer patients [7]. Validity and Reliability test was also conducted and in conclusion, the questionnaire can be used in patients with permanent pacemakers and it needs to be validated in other groups, such as breast cancer patients.

\section{Statistical Analysis}

This cross-sectional study was ethically approved by The Health Research Ethics Committee of Faculty of Medicine Universitas Sebelas Maret on June 27, 2018 no.118/UN27.6/KEPK/2018. A minimum of 30 samples is needed to conduct validity and reliability test. Construct validity was measured by referring to Pearson's $r$ table correlation value and reliability was measured by referring to Cronbach's alpha coefficient. The value of Pearson's $r$ table must be $>0.1548$ and Cronbach's alpha coefficient must be more than 0.70 .
Demographical data were also asked to the respondents including age, occupancy, education, marital status, stadium, duration of illness, therapy, and whether the respondents had a comorbid illness or not. The data were collected and then analyzed by using IBM SPSS Statistics 21 for Windows.

\section{RESULTS}

Table 1. Subject characteristics

\begin{tabular}{|c|c|c|}
\hline Characteristics & $\begin{array}{l}\text { Frequency } \\
(n=114)\end{array}$ & $(\%)$ \\
\hline \multicolumn{3}{|l|}{ Age } \\
\hline$<40$ & 21 & 18,42 \\
\hline $41-50$ & 51 & 44,74 \\
\hline $51-60$ & 37 & 32,46 \\
\hline$>60$ & 5 & 4,39 \\
\hline \multicolumn{3}{|l|}{ Education } \\
\hline Elementary School & 2 & 1,75 \\
\hline Junior High School & 10 & 8,77 \\
\hline Senior High School & 40 & 35,09 \\
\hline Diploma & 15 & 13,16 \\
\hline Bachelor Degree & 41 & 35,96 \\
\hline Master Degree & 6 & 5,26 \\
\hline \multicolumn{3}{|l|}{ Occupancy } \\
\hline Occupied & 62 & 54,39 \\
\hline Not occupied & 52 & 45,61 \\
\hline \multicolumn{3}{|l|}{ Marital Status } \\
\hline Single & 5 & 4,39 \\
\hline Married & 94 & 82,46 \\
\hline Widow & 15 & 13,16 \\
\hline \multicolumn{3}{|l|}{ Stadium } \\
\hline 1 & 15 & 13,16 \\
\hline 2 & 62 & 54,39 \\
\hline 3 & 37 & 32,46 \\
\hline \multicolumn{3}{|l|}{ Duration of illness } \\
\hline $0-6$ months & 7 & 6,14 \\
\hline 7-12 months & 10 & 8,77 \\
\hline 13-24 months & 34 & 29,82 \\
\hline $25-60$ months & 46 & 40,35 \\
\hline$>60$ months & 15 & 13,16 \\
\hline \multicolumn{3}{|l|}{ Therapy } \\
\hline None & 42 & 36,84 \\
\hline Chemotherapy/radiotherapy & 9 & 7,89 \\
\hline Other & 63 & 55,26 \\
\hline \multicolumn{3}{|l|}{ Comorbid illness } \\
\hline Yes & 23 & 20,18 \\
\hline No & 91 & 79,82 \\
\hline
\end{tabular}


Table 2. Pearson's $r$ value and Cronbach's alpha coefficient for all RAND SF-36 questions

\begin{tabular}{|c|c|c|}
\hline Subscale and its items & $\begin{array}{l}\text { Pearson's } \\
\text { r value }\end{array}$ & $\begin{array}{l}\text { Cronbach's } \\
\text { Alpha }\end{array}$ \\
\hline \multicolumn{3}{|l|}{ Physical Functioning (PF) } \\
\hline 3. Vigorous activities & 0,563 & 0,923 \\
\hline 4. Moderate activities & 0,511 & 0,923 \\
\hline 5. Lift and carry groceries & 0,624 & 0,922 \\
\hline 6. Climb several flights of stairs & 0,593 & 0,922 \\
\hline 7. Climb one flight of stairs & 0,524 & 0,923 \\
\hline 8. Bend, kneel or stoop & 0,455 & 0,924 \\
\hline 9. Walk more than a kilometer & 0,536 & 0,923 \\
\hline 10. Walk several hundred meters & 0,455 & 0,924 \\
\hline 11. Walk a hundred meter & 0,411 & 0,924 \\
\hline 12. Bath or dress & 0,398 & 0,925 \\
\hline \multicolumn{3}{|l|}{ Role Physical (RP) } \\
\hline 13. Cut down amount of time & 0,681 & 0,921 \\
\hline 14. Accomplished less & 0,705 & 0,921 \\
\hline 15. Limited work & 0,723 & 0,920 \\
\hline 16. Difficulty in performing work & 0,704 & 0,921 \\
\hline \multicolumn{3}{|l|}{ Role Emotional (RE) } \\
\hline 17. Cut down amount of time & 0,719 & 0,920 \\
\hline 18. Accomplished less & 0,706 & 0,921 \\
\hline $\begin{array}{l}\text { 19. Inability to do work as carefully } \\
\text { as usual }\end{array}$ & 0,573 & 0,923 \\
\hline \multicolumn{3}{|l|}{ Vitality (VT) } \\
\hline 23. Feel full up pep & 0,379 & 0,925 \\
\hline 27. Have a lot of energy & 0,580 & 0,923 \\
\hline 29. Feel worn out & 0,365 & 0,925 \\
\hline 31. Feel tired & 0,498 & 0,924 \\
\hline \multicolumn{3}{|l|}{ Mental Health (MH) } \\
\hline 24. Being a very nervous person & 0,194 & 0,926 \\
\hline 25. Felt so down in the dumps & 0,446 & 0,924 \\
\hline 26. Felt calm or peaceful & 0,478 & 0,924 \\
\hline 28. Felt downhearted and blue & 0,317 & 0,925 \\
\hline 30. Being a happy person & 0,533 & 0,924 \\
\hline \multicolumn{3}{|l|}{ Social Function (SF) } \\
\hline $\begin{array}{l}\text { 20. Extent of problems interfered } \\
\text { with social activities }\end{array}$ & 0,493 & 0,924 \\
\hline 32. Time-limited health to society & 0,327 & 0,925 \\
\hline \multicolumn{3}{|l|}{ Bodily Pain (BP) } \\
\hline 21. Had bodily pain & 0,471 & 0,924 \\
\hline $\begin{array}{l}\text { 22. Interfere pain with normal } \\
\text { work }\end{array}$ & 0,498 & 0,924 \\
\hline \multicolumn{3}{|l|}{ General Health (GH) } \\
\hline 1. Health in general & 0,441 & 0,924 \\
\hline 33. Getting sick easier & 0,356 & 0,925 \\
\hline 34. As healthy as anybody & 0,342 & 0,925 \\
\hline 35. Health expectation & 0,285 & 0,925 \\
\hline 36. Excellent health & 0,538 & 0,924 \\
\hline \multicolumn{3}{|l|}{ Health Changes } \\
\hline $\begin{array}{l}\text { 2. Health difference to one year } \\
\text { ago }\end{array}$ & 0,287 & 0,924 \\
\hline
\end{tabular}

Table 1 shows the characteristic of the respondents of this study. All of the respondents were female with mean age of 48 years old. Based on the educational status, most of the respondents graduated from senior high school (35.09\%) and bachelor degree (35.96\%). Most of the respondents were married (82.46\%) and had stage 2 of breast cancer (54.39\%). Only a few of the subjects were having chemotherapy or radiotherapy (7.89\%) when the research was conducted.

Table 2 shows Pearson's $r$ value and Cronbach's alpha coefficient for all RAND SF-36 questions. Pearson's value of all items of the questionnaire shows $r>0.1548$ with the lowest value of $r=0,194$ in item number 24 , followed by $r=0,285$ in item number 35 , and $r=0,287$ in item number 2. Other than that, all items showed the value of $r>0,300$. Cronbach's alpha coefficient in all items shows value $>0,900$, between the range of 0,920 and 0,926 , supporting the internal consistency of the subscales.

\section{DISCUSSION}

The mean age of participants was 48 years with 24 year-old as the youngest and 69-year-old as the oldest participant. The mean age was similar to studies in Korea and India with a mean age of 47.7 and 47.6 years old, respectively $[10,11]$. Most of the participants were on stage II (54.8\%) and almost all of the participants (84.2\%) already completed the treatment series (surgery, chemotherapy and/or radiotherapy).

The validity of Indonesian RAND SF-36 was done by evaluating the construct validity and reliability, referring to Pearson's $r>0.1548$ and Cronbach's alpha $>0.70$. All items showed $r>0.1548$ so that all items of RAND SF-36 are valid and reflected the concepts. Cronbach's alpha showed value $>0.90$ ranging around $0,920-0,926$. It means that all items had satisfying internal consistency.

Despite all questions showed the value of $r>0.1548$, some questions had a lower value than the others. Question number 24 (Mental Health) had the lowest value, showing $r=0,194$. Research by Perwitasari [8] that was conducted in patients with cancer disease also had questions that did not meet the criteria of convergency nor discriminant validity, mainly from the mental health domain. Other questions that have a quiet low value than the others $(r<0,300)$ are question number 2 (Health Changes) with Pearson's $r$ value of 0,287 and question number 35 (General Health) with Pearson's $r$ value of 0,285 . Research held by Novitasari et al. [6], and Perwitasari [8] also showed almost the same thing that question number 35 did not meet discriminant validity in rheumatoid arthritis patients and question number 2 also did not meet discriminant validity in patients with cancer disease $[6,8]$. All those three questions are associated with Mental Health domain and the explanation related to this low value might be because 
the respondents had hard times to translate what they exactly feel into words. Overall, based on the Pearson's $r$ and Cronbach's alpha value, all questions were valid and reliable and could be used as an instrument to assess the quality of life especially in patients with breast cancer disease.

This study also has some limitations. Validity and reliability tests for other quality of life instrument did not just only analyze the validity by referring to its Pearson's $r$ value, but also did other validity tests such as convergent and discriminant validity, known-groups validity, and also factor analysis [6-8, 12-14]. Further validity and reliability test in other groups is also needed.

\section{CONCLUSION}

The Indonesian version of the SF-36 quality of life questionnaire is valid and reliable. It is a suitable instrument and can be used for research in Indonesian breast cancer patients.

\section{DECLARATIONS}

\section{Competing of Interest}

The authors declare no competing interests.

\section{Acknowledgment}

We thank all community members, Dr. dr. Widyanti Soewoto, Sp.B(K)Onk., friends, and all people that helped to participate in this study.

\section{REFERENCES}

1. Ferlay J, Soerjomataram I, Dikshit R, Eser S, Mathers C, Rebelo $\mathrm{M}$ et al. Cancer incidence and mortality worldwide: Sources, methods and major patterns in GLOBOCAN 2012. Int J Cancer. 2014;136(5):E359E386.

2. Kementerian Kesehatan Republik Indonesia. Pedoman Nasional Pelayanan Kedokteran Kanker Payudara. Komite Penanggulangan Kanker Nasional. 2017.

3. Kementerian Kesehatan Republik Indonesia. Bulan Peduli Kanker Payudara. Pusat Data dan Informasi. 2016.
4. Verdugo M, Schalock R, Keith K, Stancliffe R. Quality of life and its measurement: important principles and guidelines. J Intellect Disabil Res. 2005;49(10):707-717.

5. Feeny DH, Eckstrom E, Whitlock EP, Perdue LA. A Primer for systematic reviewers on the measurement of functional status and healthrelated quality of life in older adults. Agency for Healthcare Research and Quality. 2013.

6. Novitasari L, Perwitasari D, Khoirunisa S. Validity of short form 36 (SF-36) Indonesian version on rheumatoid arthritis patients. Jurnal Kedokteran dan Kesehatan Indonesia. 2016;7(3):80-86.

7. Salim S, Yamin M, Alwi I, Setiati S. Validity and reliability of Indonesian version of SF-36 quality of life questionnaire on patients with permanent pacemakers. Acta Med Indones. 2017;49;(1);10-16.

8. Perwitasari D. Development the validation of Indonesian version of SF-36 questionnaire in cancer disease. Indonesian Journal of Pharmacy. 2012;23(4):248-53

9. Ware J, Sherbourne C. Erratum to The MOS 36-item short form health survey (SF-36): I. Conceptual framework. Pharmacoeconomics. 1992;2(2).

10. Chang O, Choi E, Kim I, Nam S, Lee J, Lee S et al. Association between socioeconomic status and altered appearance distress, body image, and quality of life among breast cancer patients. Asian Pac J Cancer Prev. 2014;15(20):8607-8612.

11. Ramadas A, Qureshi A, Dominic N, Botross N, Riad $A$, Arasoo $V$ et al. Socio-demography and medical history as predictors of health-related quality of life of breast cancer survivors. Asian Pac J Cancer Prev. 2015;16(4):1479-1485.

12. Anindito B, Hidayat R, Koesnoe S, Dewiasty $E$. Validity and reliability of lupus quality of life questionnaire in patients with systemic lupus erythematosus in Indonesia. Indonesian Journal of Rheumatology. 2016;8(2):38-44.

13. Pinar R. Reliability and construct validity of the SF36 in Turkish cancer patients. Qual Life Res. 2005; 14(1):259-264.

14. Perwitasari D, Atthobari J, Dwiprahasto I, Hakimi M, Gelderblom $\mathrm{H}$, Putter $\mathrm{H}$ et al. Translation and validation of EORTC QLQ-C30 into Indonesian version for cancer patients in Indonesia. Jpn J Clin Oncol. 2011;41(4):519-529. 